\title{
Effects of invasive cordgrass on crab distributions and diets in a Chinese salt marsh
}

\author{
Haiming Qin ${ }^{1}$, Tianjiang $\mathrm{Chu}^{1}$, Wang $\mathrm{Xu}^{1}$, Guangchun Lei ${ }^{2}$, Zhongbin Chen ${ }^{1}$, \\ Weimin Quan ${ }^{1}$, Jiakuan Chen ${ }^{1}$, Jihua $\mathrm{Wu}^{1, *}$ \\ ${ }^{1}$ Ministry of Education Key Laboratory for Biodiversity Science and Ecological Engineering, Institute of Biodiversity Science, \\ Fudan University, Shanghai 200433, PR China \\ ${ }^{2}$ School of Nature Conservation, Beijing Forestry University, Beijing 100083, PR China
}

\begin{abstract}
The effects of invasive cordgrass Spartina alterniflora on burrowing crab communities in the salt marshes of the Yangtze River Estuary, China, were studied. Crab abundance, distribution and diets were compared in native Phragmites australis and invasive S. alterniflora stands. Spartinainvaded stands had $42 \%$ higher crab density than did native $P$. australis stands, largely because 2 dominant grapsoid crabs, Helice tientsinensis and Chiromantes dehaani, thrived in S. alterniflora stands. Sediment grain size, water content and vegetation stem height were the main factors correlated with crab distributions. Crab diet analyses revealed that crab stomach fullness was similar in stands of different plant species, indicating that in Spartina-invaded stands crabs can find compatible food quantity as in native plant stands. Both $H$. tientsinensis and C. dehaani from $S$. alterniflora stands had significantly higher $\delta^{13} \mathrm{C}$ values than those from $P$. australis stands, suggesting that the crabs consumed $S$. alterniflora in the invasive marshes. This non-selective feeding may be driving the success of $H$. tientsinensis and C. dehaani in invasive Spartina stands.
\end{abstract}

KEY WORDS: Herbivores - Invasive species $\cdot$ Spartina alterniflora $\cdot$ Phragmites australis $\cdot$ Feeding habits · Gut contents $\cdot$ Stable isotopes · Yangtze River estuary

\section{INTRODUCTION}

In salt marsh ecosystems, burrowing crabs influence sediment, plants and other marsh organisms physically. Fiddler crabs can enhance the growth of Spartina alterniflora and the abundance of meiofauna by aerating the sediment (Hoffman et al. 1984, Bertness 1985). Helice spp., a common and widely distributed crab in saltmarsh habitats, might prevent the outflow of primary products of Phragmites australis from the salt marsh to open shores (Takeda \& Kurihara 1987). Substrate excavation by burrowing crabs can turn over marsh sediments, bring buried material to the marsh surface, expose the sediments to oxygen, change the amount of material that is imported or exported by tidal flushing and, thus, play an important role in the circulation of nutrients within the salt marsh ecosystems (McCraith et al. 2003, Minkoff et al. 2006, Escapa et al. 2008, Fanjul et al. 2008).
Salt marshes are vulnerable to various disturbances including biological invasions (Grosholz 2002, Levin et al. 2006). The introduction of exotic plant species in salt marshes has occurred worldwide, and has affected native invertebrate communities (Talley \& Levin 2001, Posey et al. 2003, Neira et al. 2006). The changes in vegetation type that instigate changes in sediment properties might influence the abundance and distribution of burrowing crabs as well as the services they provide to the marsh systems. The effects of plant invasions on burrowing crabs, however, have not received much attention. To date, only 2 studies assessed the influence of plant invasions on marsh crabs and each emphasized a certain crab species. Jivoff \& Able (2003) reported that the feeding molt stage of juvenile blue crabs Callinectes sapidus preferred native cordgrass Spartina alterniflora to invasive Phragmites australis in marshes of Delaware Bay, USA. Wang et al. (2008) found that the abundance and biomass of Sesarma dehaani (i.e. Chi- 
romantes dehaani) were significantly greater in the invasive $S$. alterniflora than in native $P$. australis stands in the Yangtze River estuary, China. The effects of plant invasions on crab communities are still largely unknown. Since different crab species influence sediment properties differently, understanding the modification of whole crab communities and their functions induced by plant invasions is important.

To mitigate erosion control and enhance sediment accretion, Spartina alterniflora was intentionally introduced from North America to China in 1979. This led to a rapid range expansion along the Chinese coast (Li et al. 2009). $S$. alterniflora became a dominant plant in wetland ecosystems at Dongtan on Chongming Island in just over $10 \mathrm{yr}$ since its introduction, and its effect on native biodiversity has become evident (Wang et al. 2006, Chen et al. 2007). Wang et al. (2008) investigated the influence of $S$. alterniflora invasions on the crab Chiromantes dehaani by using traps. However, how the crab communities respond to the exotic $S$. alterniflora remains unclear.

Plant communities provide food, liv-

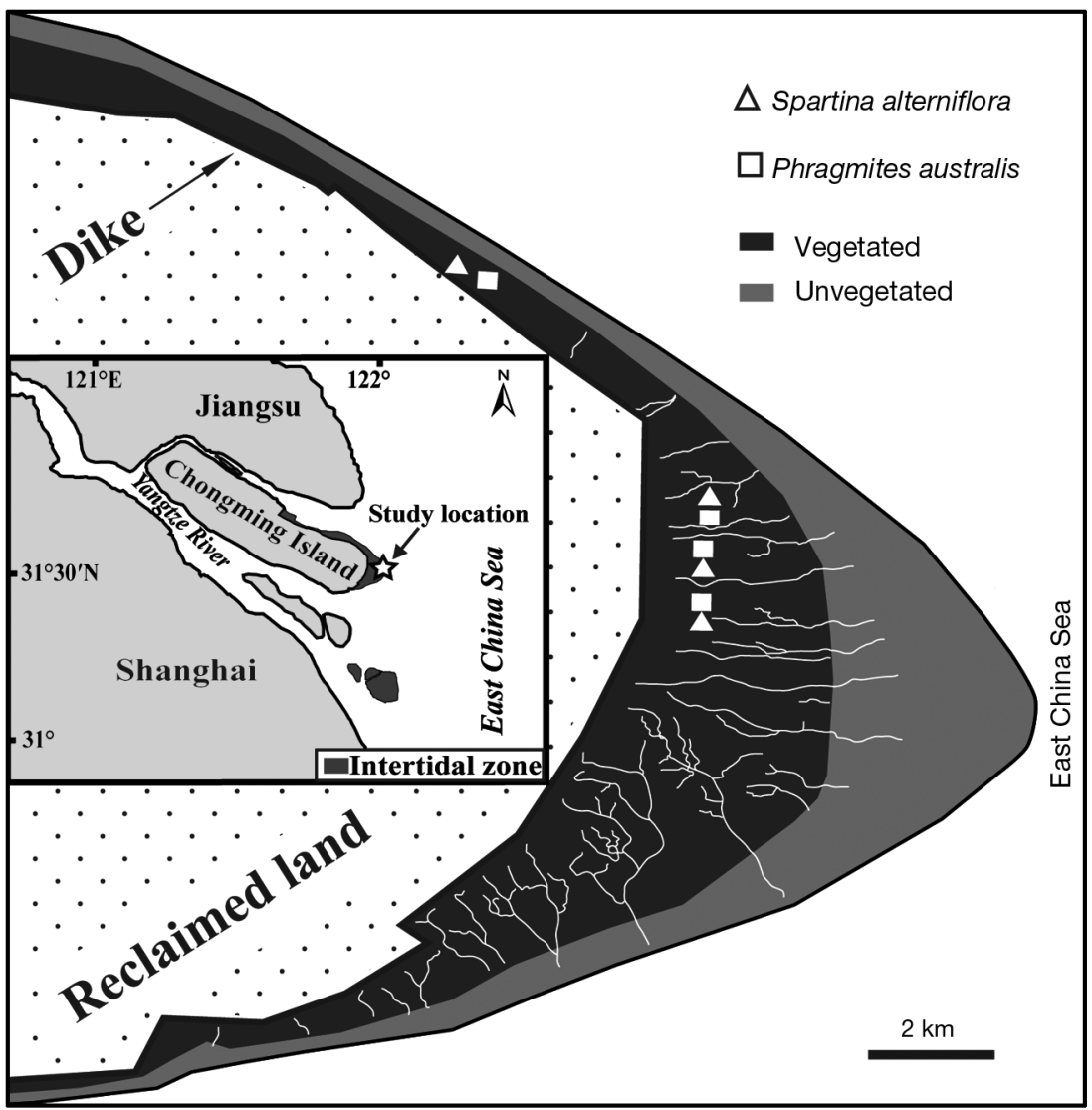

Fig. 1. Chongming Dongtan at the Yangtze River estuary showing locations of sampling sites

ing habitats and nursery grounds for benthic organisms; therefore, the mechanisms underlying the shifts in zoobenthic communities due to plant invasions are site and species specific. Among these mechanisms, the feeding habits of organisms are undoubtedly one of the most important. Saltmarsh crabs can be important grazers, predators or deposit feeders with different selectivity on various food types (Bertness 1999). However, the relationship between the feeding preference and the distribution of crabs is still unclear (Bertness \& Miller 1984, Bortolus et al. 2002). By studying crabs in adjacent native Phragmites australis and exotic Spartina alterniflora stands and quantifying crab diets, the present study examined: (1) whether the distribution of crabs is influenced by the $S$. alterniflora invasion of the Yangtze River estuary salt marshes and (2) whether the modifications of crab distributions are related to their feeding activities.

\section{MATERIALS AND METHODS}

Study site. The study was conducted at the Chongming Dongtan National Nature Reserve $\left(121^{\circ} 50^{\prime}\right.$ to $122^{\circ} 05^{\prime} \mathrm{E}, 31^{\circ} 25^{\prime}$ to $31^{\circ} 38^{\prime} \mathrm{N}$ ) on the Yangtze River estuary in eastern China (Fig. 1). The study site $\left(241.55 \mathrm{~km}^{2}\right)$ is characterized by a warm, humid, subtropical monsoonal climate, with annual mean temperature and mean precipitation of $15.3^{\circ} \mathrm{C}$ and $1022 \mathrm{~mm}$, respectively. The intertidal areas are flooded by semidiurnal tides with a maximum range of 4.62 to $5.95 \mathrm{~m}$ and an average tidal height range of 1.96 to $3.08 \mathrm{~m}$. The invasive plant species Spartina alterniflora has rapidly expanded at Dongtan marshes by forming pure stands that constitute up to $33.1 \%$ of the total vegetation coverage (Huang et al. 2005).

Sampling design and crab sample processing. Common borrowing crab species at the studied marshes include 3 species from the family Ocypodidae (Uca arcuata, Ilyoplax deschampsi and Macrophthalmus abbreviatus) and 3 species from Grapsidae (Helice tientsinensis, Chiromantes haematocheir and $C$. dehaani) (Xu \& Zhao 2005). These crabs have various feeding habits and potential food sources include vascular plants, microalgae and animal items.

Within the intertidal marshes of the reserve, 4 blocks were chosen at an elevation of $\sim 3.8 \mathrm{~m}$ from which to collect crabs (Fig. 1). In each block, there were monoculture patches of both native Phragmites australis and 
invasive Spartina alterniflora. The diameter of each monoculture patch was $>50 \mathrm{~m}$. Sampling was done at spring tides on 20 November 2007, and on 18 January, 2 April and 25 June 2008, to represent autumn, winter, spring and summer, respectively. In each block at each sampling date, 3 randomly placed $50 \times 50 \mathrm{~cm}$ quadrats were selected in $P$. australis and $S$. alterniflora monocultures. From within the quadrat, crabs were collected from the sediment surface, and those in burrows were obtained by digging them out (Spivak et al. 1996, Bas et al. 2005). Additional crabs were also collected seasonally for stomach content analyses. All crabs captured were preserved in $10 \%$ formalin in labeled plastic bottles. In the laboratory, crabs were identified, counted and weighted. The nomenclature of crabs followed $\mathrm{Ng}$ et al. (2008).

Environmental parameters. Sediment temperature and electrical conductivity were measured directly at $10 \mathrm{~cm}$ depth in each crab sampling quadrat. One sediment sample was collected from each quadrat with a PVC tube $3.2 \mathrm{~cm}$ in diameter to a depth of $10 \mathrm{~cm}$ for water content and grain size analyses. In the laboratory, water content was assessed by drying the samples at $80^{\circ} \mathrm{C}$ for $48 \mathrm{~h}$. Sediment grain size was determined using a LS100Q laser grain sizer. Live plant stem densities were recorded by counting the shoots from 3 additional $25 \times 25 \mathrm{~cm}$ quadrats, and stem height was determined by measuring 15 random stems per plant species per block.

Stomach content analyses. Stomachs of the 2 dominant crab species were excised from specimens collected during the 4 seasons. Stomach fullness was visually assessed according to the criteria of Johnston \& Freeman (2005) and placed into 5 classes: $1=$ empty, $2=25 \%, 3=50 \%, 4=75 \%$ and $5=100 \%$ full. For stomach content analyses, 10 crabs with stomach fullness from 50 to $100 \%$ were selected for each vegetation area in each season. The stomachs were cut open and the contents were washed with distilled water into a $10 \mathrm{~cm}$ diameter dish. The contents in the dish were stirred evenly and examined under a binocular microscope (Olympus SZ-CTV). For each specimen, 10 visual fields were chosen randomly and photos were taken under an $11 \times$ ocular objective with the photo system (NIS-Elements D 2.20). A grid $(100 \times 100 \mu \mathrm{m})$ was added simultaneously to the image by means of the photo system. The relative abundance of each dietary item was counted in the field they occupied and 4 categories of food types from stomach contents were determined. Animal materials included gastropods, insects, isopods, crustaceans, fish and invertebrate eggs and scales. Plant materials included rhizomes/roots, stems, leaves, inflorescence, seeds and buds. Unidentified organic matter was placed in the organic debris category, and inorganic debris mainly consisted of sand, clay, plastic and other unidentified materials.

Stable isotope analyses. Samples for stable isotope analyses were collected in July and October when the plants had the highest biomass. Samples of Phragmites australis and Spartina alterniflora were collected by hand at ebb tides. Leaves from 10 plants were pooled as a single sample.

Benthic microalgae (BMI) samples were collected from the monocultures of the 2 vegetation types at ebb tide by the modified technique of Riera et al. (1999). Briefly, the sediment surface was covered with a $5 \mathrm{~mm}$ thick layer of pre-combusted commercial sand, a piece of $63 \mu \mathrm{m}$ nylon mesh and another $5 \mathrm{~mm}$ thick layer of pre-combusted sand and left to incubate for $3 \mathrm{~h}$. After $3 \mathrm{~h}$, the sand layer was scraped off and mixed with prefiltered creek water. The water-sand mixture was shaken and the supernatant was filtered through precombusted GF/F filters (Whatman).

Crabs for stable isotope analyses were collected from vegetated zones of the marshes. Muscle tissue from approximately 10 individuals of each crab species from each plant monoculture type were pooled for analysis.

All plant and animal materials were first treated with $1 \mathrm{~N} \mathrm{HCl}$ to eliminate the carbonates and then were oven dried at $60^{\circ} \mathrm{C}$. Stable carbon and nitrogen isotope ratios were measured by continuous-flow isotope ratio mass (IRM) spectrometry using a Finnigan Delta-plus IRM spectrometer interfaced with a Flash EA 1112 Series at the Institute of Botany, Chinese Academy of Sciences. Urea and glycine were used as accuracy and precision standards for isotopic ratios. All stable isotope abundances are expressed using the $\delta$ notation as $\%$ differences from an international standard (Vienna Pee Dee Belemnite for carbon, air for nitrogen):

$$
\delta X=\left[\left(R_{\text {sample }} / R_{\text {standard }}\right)-1\right] \times 10^{3},
$$

where $X$ is ${ }^{13} \mathrm{C}$ or ${ }^{15} \mathrm{~N}$, and $R$ is the corresponding isotope ratio of ${ }^{13} \mathrm{C} /{ }^{12} \mathrm{C}$ or ${ }^{15} \mathrm{~N} /{ }^{14} \mathrm{~N}$. The analytical precision of these measurements was $0.20 \%$ for $\delta^{13} \mathrm{C}$ and $0.30 \%$ o for $\delta^{15} \mathrm{~N}$.

Since the exotic Spartina alterniflora and the native Phragmites australis are $\mathrm{C}_{4}$ and $\mathrm{C}_{3}$ plants, respectively, the $\delta^{13} \mathrm{C}$ value for $S$. alterniflora is expected to be higher than that for $P$. australis. If the crabs are nonselective in feeding and can consume $S$. alterniflora in exotic marshes, they would have higher $\delta^{13} \mathrm{C}$ values than those from native marshes.

Data analyses. Nested 2-way ANOVA with 2 main factors (Plant type and Season) was used to evaluate the effects of plant type and season on sediment properties, plant traits and crabs. Proportional data were $\operatorname{arcsine}(x)$-transformed before analysis. When effects were significant, multiple comparisons between plant types were made based on least square means. Differ- 
ences were regarded as significant at $p<0.05$. The BIO-ENV procedure was used to identify the environmental variables that best explained variations in crab communities (Clarke \& Ainsworth 1993). The BIOENV analysis used Spearman's rank correlation between the resulting ranked similarity matrices of crabs and the rank similarity matrix obtained through Euclidean distances using the standardized environmental variables. All analyses were performed using Statistica 7.0 and PRIMER 5.

Two-way ANOVA was performed to test the effects of season and habitat on crab stomach fullness. The differences in relative abundance of each dietary item in crabs from different plant communities were analyzed by a $t$-test. Before analysis, the proportional data were $\operatorname{arcsine}(x)$-transformed. One-way ANOVA was applied to test the difference in $\delta^{13} \mathrm{C}$ and $\delta^{15} \mathrm{~N}$ values among autotrophs and among crabs. Differences were regarded as significant at $\mathrm{p}<0.05$.

\section{RESULTS}

\section{Environmental factors}

The proportions of different sediment grains, sediment water content, temperature, stem density and height differed significantly between the 2 plant types (Table 1). Silt and clay constituted the majority of sediment $(>90 \%)$ in most samples. The sediment in Spartina alterniflora patches had a lower proportion of silt than that in Phragmites australis patches. The temperature in $S$. alterniflora stands was generally higher than in P. australis stands except in April. Sediment water content ranged from 27.92 to $37.41 \%$; significantly higher water content was found in S. alterniflora compared with $P$. australis communities in most months. The stems of $S$. alterniflora were generally denser than those of $P$. australis. In April, $S$. alterniflora had higher stems than $P$. australis. After June, P. australis exceeded $S$. alterniflora in stem height.

\section{Crab communities}

During the study, a total of 308 crabs belonging to 4 species from 3 families were captured; 181 crabs were collected in Spartina alterniflora and 127 crabs in Phragmites australis communities (Table 2). The density and biomass of the total crabs differed significantly between $S$. alterniflora and $P$. australis monocultures, with higher values found in $S$. alterniflora patches (Table 3). No significant difference in species richness was found between the 2 plant types. BIOENV analysis revealed that the stem height was the environmental variable that best explained the variations in the crab communities (correlation coefficient $=0.129$ ). In combination, 4 environmental variables (temperature, water content, sand proportion and stem height) were closely correlated with the variations in crab communities, with the maximum correlation coefficient of 0.143 .

Numerically, Helice tientsinensis and Chiromantes dehaani were the dominant crab species in both Spartina alterniflora and Phragmites australis communities, together constituting over $75 \%$ of the total crab

Table 1. Sediment properties and vegetation characteristics of Spartina alterniflora (SA) and Phragmites australis (PA) marshes in each sampling month. Shown are the mean values with SE in parentheses and the summary of nested 2-way ANOVA ( $F$-values with significance levels in parentheses; significant differences $\mathrm{p}<0.05$ are indicated in bold text). Blocks were nested within plants and time. Different superscript letters $(\mathrm{a}, \mathrm{b})$ indicate significant differences between SA and PA in each month $(\mathrm{p}<0.05)$

\begin{tabular}{|c|c|c|c|c|c|c|c|c|c|c|}
\hline Mo & Plant & $\mathrm{n}$ & $\begin{array}{c}\text { Clay } \\
<4 \mu \mathrm{m}(\%)\end{array}$ & $\begin{array}{c}\text { Silt } \\
4-63 \mu \mathrm{m}(\%)\end{array}$ & $\begin{array}{c}\text { Sand } \\
>63 \mu \mathrm{m}(\%)\end{array}$ & $\begin{array}{c}\text { Temperature } \\
\left({ }^{\circ} \mathrm{C}\right)\end{array}$ & $\begin{array}{c}\text { Water } \\
\text { content (\%) }\end{array}$ & $\begin{array}{l}\text { Electrical } \\
\text { conductivity } \\
\left(\mathrm{mS} \mathrm{cm}^{-1}\right)\end{array}$ & $\begin{array}{c}\text { Stem } \\
\text { density } \\
\text { (ind. } \mathrm{m}^{-2} \text { ) }\end{array}$ & $\begin{array}{l}\text { Stem } \\
\text { height } \\
(\mathrm{cm})\end{array}$ \\
\hline \multirow[t]{2}{*}{ Nov } & SA & 12 & $22.43(3.17)^{\mathrm{a}}$ & $63.74(2.91)^{\mathrm{a}}$ & $13.83(4.57)^{\mathrm{a}}$ & $12.97(0.29)$ & $31.34(0.68)$ & & $592(45)$ & $131.5(14.7)^{\mathrm{a}}$ \\
\hline & PA & 12 & $27.59(2.97)^{\mathrm{b}}$ & $69.80(2.26)^{b}$ & $2.61(0.78)^{b}$ & $12.89(0.38)$ & $32.70(1.17)$ & & $524(43)$ & $151.4(25.8)^{\mathrm{b}}$ \\
\hline \multirow[t]{2}{*}{ Jan } & SA & 12 & $29.28(1.00)$ & $70.26(0.84)$ & $0.46(0.19)$ & $12.78(0.52)^{\mathrm{a}}$ & $33.62(1.43)^{\mathrm{a}}$ & & $308(33)^{\mathrm{a}}$ & $112.6(15.4)^{\mathrm{a}}$ \\
\hline & PA & 12 & $27.83(0.49)$ & $71.66(0.40)$ & $0.51(0.15)$ & $11.55(0.55)^{\mathrm{b}}$ & $29.71(0.93)^{\mathrm{b}}$ & & $252(47)^{\mathrm{b}}$ & $165.2(20.8)^{\mathrm{b}}$ \\
\hline \multirow[t]{2}{*}{ Apr } & SA & 12 & $29.79(0.85)^{\mathrm{a}}$ & $69.70(0.78)^{\mathrm{a}}$ & $0.51(0.14)^{\mathrm{a}}$ & $11.72(0.31)^{\mathrm{a}}$ & $32.09(0.91)^{\mathrm{a}}$ & $5.82(0.45)$ & $374(67)^{\mathrm{a}}$ & $19.4(4.32)^{\mathrm{a}}$ \\
\hline & PA & 12 & $26.06(0.69)^{\mathrm{b}}$ & $72.64(0.46)^{\mathrm{b}}$ & $1.30(0.27)^{b}$ & $12.47(0.13)^{\mathrm{b}}$ & $28.26(0.39)^{b}$ & $5.29(0.26)$ & $142(12)^{b}$ & $17.81(2.85)^{b}$ \\
\hline \multirow[t]{2}{*}{ Jun } & SA & 12 & $31.90(1.30)^{\mathrm{a}}$ & $67.80(1.23)^{\mathrm{a}}$ & $0.30(0.09)$ & $23.31(0.16)$ & $37.41(1.51)^{\mathrm{a}}$ & $5.62(0.31)$ & $238(24)$ & $100.3(14.36)^{\mathrm{a}}$ \\
\hline & $\mathrm{PA}$ & 12 & $27.32(0.89)^{\mathrm{b}}$ & $72.03(0.76)^{\mathrm{b}}$ & $0.65(0.16)$ & $23.25(0.13)$ & $27.92(0.71)^{\mathrm{b}}$ & $5.17(0.38)$ & 196 (19) & $161.0(36.64)^{\mathrm{b}}$ \\
\hline \multicolumn{11}{|c|}{ Summary of nested 2-way ANOVA } \\
\hline \multicolumn{2}{|c|}{ Plant } & & $6.81(0.011)$ & $39.31(<0.001)$ & $10.07(0.002)$ & $5.04(0.028)$ & $104.68(<0.001)$ & $3.874(0.058)$ & $64.18(<0.001)$ & $355.04(<0.001)$ \\
\hline \multicolumn{3}{|l|}{ Time } & $37.57(<0.001)$ & $10.78(<0.001)$ & $86.27(<0.001)$ & $3442.00(<0.001)$ & $7.04(<0.001)$ & $0.406(0.529)$ & $98.70(<0.001)$ & $1947.58(<0.001)$ \\
\hline \multicolumn{3}{|c|}{ Plant $\times$ Time } & $37.68(<0.001)$ & $2.77(0.049)$ & $42.18(<0.001)$ & $40.66(<0.001)$ & $32.07(<0.001)$ & $0.022(0.883)$ & $12.62(<0.001)$ & $28.08(<0.001)$ \\
\hline \multicolumn{3}{|c|}{$\begin{array}{l}\text { Block (Plant } \times \\
\text { Time) }\end{array}$} & $37.50(<0.001)$ & $8.71(<0.01)$ & $24.79(<0.001)$ & $44.02(<0.001)$ & $10.17(<0.001)$ & $5.013(<0.001)$ & $10.84(<0.001)$ & $18.41(<0.001)$ \\
\hline
\end{tabular}


Table 2. Crab species captured in Spartina alterniflora and Phragmites australis communities during the study. Shown are abundance (individual), biomass ( $\mathrm{g}$ ) and percentage contribution of abundance (\%)

\begin{tabular}{|c|c|c|c|c|c|c|c|}
\hline \multirow[t]{2}{*}{ Family } & \multirow[t]{2}{*}{ Crab species } & \multicolumn{3}{|c|}{ — Spartina alterniflora patches } & \multicolumn{3}{|c|}{ —Phragmites australis patches } \\
\hline & & Abundance & Biomass & Percentage & Abundance & Biomass & Percentage \\
\hline Varunidae & Helice tientsinensis & 85 & 648.91 & 46.96 & 51 & 411.625 & 40.16 \\
\hline \multirow[t]{2}{*}{ Sesarmidae } & Chiromantes dehaani & 80 & 912.25 & 44.20 & 48 & 604.584 & 37.79 \\
\hline & Parasesarma plicatum & 9 & 60.87 & 4.97 & 15 & 96.885 & 11.81 \\
\hline Ocypodidae & Uca arcuata & 7 & 58.19 & 3.87 & 13 & 121.519 & 10.24 \\
\hline Total & 4 & 181 & 1680.22 & 100 & 127 & 1234.613 & 100 \\
\hline
\end{tabular}

Table 3. Species richness (expressed per quadrat), density (ind. $\mathrm{m}^{-2}$ ) and biomass $\left(\mathrm{g} \mathrm{m}^{-2}\right.$ ) of all crabs and 2 numerically abundant species, Helice tientsinensis and Chiromantes dehaani, from Spartina alterniflora (SA) and Phragmites australis (PA) monocultures at each sampling time. Shown are the mean values with SE in parentheses and the summary of nested 2-way ANOVA ( $F$ values with significance levels in parentheses; significant differences $p<0.05$ are indicated in bold text). Blocks were nested within plants and time. Different superscript letters $(a, b)$ indicate significant differences between SA and PA in each month $(\mathrm{p}<0.05)$

\begin{tabular}{|c|c|c|c|c|c|c|c|c|c|}
\hline \multirow[t]{2}{*}{ Mo } & \multirow[t]{2}{*}{ Plant } & \multirow[t]{2}{*}{$\mathrm{n}$} & \multirow{2}{*}{$\begin{array}{l}\text { Species } \\
\text { richness }\end{array}$} & \multicolumn{3}{|c|}{ Density } & \multicolumn{3}{|c|}{ - Biomass- } \\
\hline & & & & All crabs & H. tientsinensis & C. dehaani & All crabs & H. tientsinensis & C. dehaani \\
\hline \multirow[t]{2}{*}{ Jan } & SA & 12 & $1.67(0.26)$ & $12.00(1.64)^{\mathrm{a}}$ & $8.00(1.12)^{\mathrm{a}}$ & $3.00(1.12)$ & $108.76(18.48)^{\mathrm{a}}$ & $66.20(9.52)^{\mathrm{a}}$ & $64.68(31.16)$ \\
\hline & PA & 12 & $1.08(0.19)$ & $6.68(1.12)^{\mathrm{b}}$ & $3.68(0.92)^{\mathrm{b}}$ & $2.32(1.36)$ & $55.68(12.76)^{\mathrm{b}}$ & $25.28(7.12)^{\mathrm{b}}$ & $26.36(14.48)$ \\
\hline \multirow[t]{2}{*}{ Apr } & SA & 12 & $1.25(0.18)$ & $19.68(3.60)^{\mathrm{a}}$ & $5.68(2.12)$ & $12.68(3.68)^{a}$ & $190.00(37.76)^{\mathrm{a}}$ & $43.12(16.32)$ & $138.12(39.84)^{\mathrm{a}}$ \\
\hline & PA & 12 & $1.83(0.21)$ & $9.68(1.36)^{b}$ & $4.00(0.68)$ & $3.68(1.16)^{b}$ & $102.72(17.88)^{\mathrm{b}}$ & $33.48(7.76)$ & $44.84(15.92)^{\mathrm{b}}$ \\
\hline \multirow[t]{2}{*}{ Jun } & SA & 12 & $1.58(0.26)$ & $18.37(3.56)$ & $5.68(1.92)$ & $10.68(2.72)$ & $174.48(37.12)$ & $32.96(11.60)$ & $126.80(32.68)$ \\
\hline & PA & 12 & $2.08(0.31)$ & $17.00(2.84)$ & $4.68(1.36)$ & $7.68(1.60)$ & $170.24(33.96)$ & $38.52(13.56)$ & $104.40(27.84)$ \\
\hline \multirow[t]{2}{*}{ Nov } & SA & 12 & $1.25(0.22)$ & $10.32(1.92)$ & $9.00(1.64)^{\mathrm{a}}$ & $0.32(0.32)$ & $86.84(14.92)$ & $74.00(14.40)^{\mathrm{a}}$ & $1.76(1.76)$ \\
\hline & PA & 12 & $1.50(0.23)$ & $9.00(1.92)$ & $4.68(1.48)^{\mathrm{b}}$ & $2.32(1.24)$ & $82.92(20.28)$ & $39.92(12.16)^{b}$ & $25.88(14.88)$ \\
\hline \multicolumn{10}{|c|}{ Summary of nested 2-way ANOVA } \\
\hline \multicolumn{3}{|c|}{ Plant } & $2.455(0.122)$ & $17.254(<0.001)$ & $10.704(0.002)$ & $9.395(0.003)$ & $9.997(0.002)$ & $7.832(0.007)$ & $6.368(0.014)$ \\
\hline \multicolumn{3}{|l|}{ Time } & $3.263(0.027)$ & $13.917(<0.001)$ & $1.037(0.382)$ & $20.184(<0.001)$ & $14.714(<0.001)$ & l) $1.812(0.154)$ & $12.593(<0.001)$ \\
\hline \multicolumn{3}{|c|}{ Plant $\times$ Time } & $4.960(0.004)$ & $3.621(0.018)$ & $1.025(0.388)$ & $7.266(<0.001)$ & $2.993(0.037)$ & $2.332(0.082)$ & 3.544 (0.019) \\
\hline \multicolumn{3}{|c|}{ Block (Plant $\times$ Time $)$} & $4.434(<0.001)$ & $6.489(<0.001)$ & $2.679(<0.001)$ & $6.257(<0.0001)$ & $6.333(<0.001)$ & 1) $2.579(0.001)$ & $4.383(<0.001)$ \\
\hline
\end{tabular}

individuals (Table 2). The density and biomass of both species differed significantly between $S$. alterniflora and $P$. australis communities (Table 3). S. alterniflora patches contained significantly more $H$. tientsinensis than $P$. australis in November and January, and significantly more C. dehaani than P. australis in April.

\section{Feeding habits of dominant crabs}

For both Helice tientsinensis and Chiromantes dehaani, 2-way ANOVA showed that the stomach fullness of crabs did not differ significantly between Spartina alterniflora and Phragmites australis communities. Both crab species had significantly higher stomach fullness in summer than in the other seasons (Fig. 2). However, in spring $H$. tientsinensis tended to eat more in $S$. alterniflora stands than in $P$. australis stands, whereas the results were opposite in summer and autumn. In contrast, C. dehaani tended to have higher stomach fullness in $P$. australis stands than in $S$. alterniflora stands in spring with the opposite trends occurring in the other seasons.

Among the 160 crab specimens examined 99.4\% contained plant materials, and only $31.9 \%$ contained animal materials. In spring, the relative abundance of plant material in the stomachs of Helice tientsinensis from Spartina alterniflora stands was significantly greater than that from Phragmites australis stands (Table 4). $H$. tientsinensis from $P$. australis areas ingested significantly more inorganic debris than in $S$. alterniflora areas. Significantly more plant material was found in the stomachs of Chiromantes dehaani from $S$. alterniflora stands than those from $P$. australis stands in autumn. C. dehaani generally ingested more inorganic debris in $S$. alterniflora areas than in $P$. australis areas, with a significant difference observed in autumn (Table 4).

Among plant materials, leaves were the most common $(98.75 \%)$ items, followed by rhizomes/roots. In 


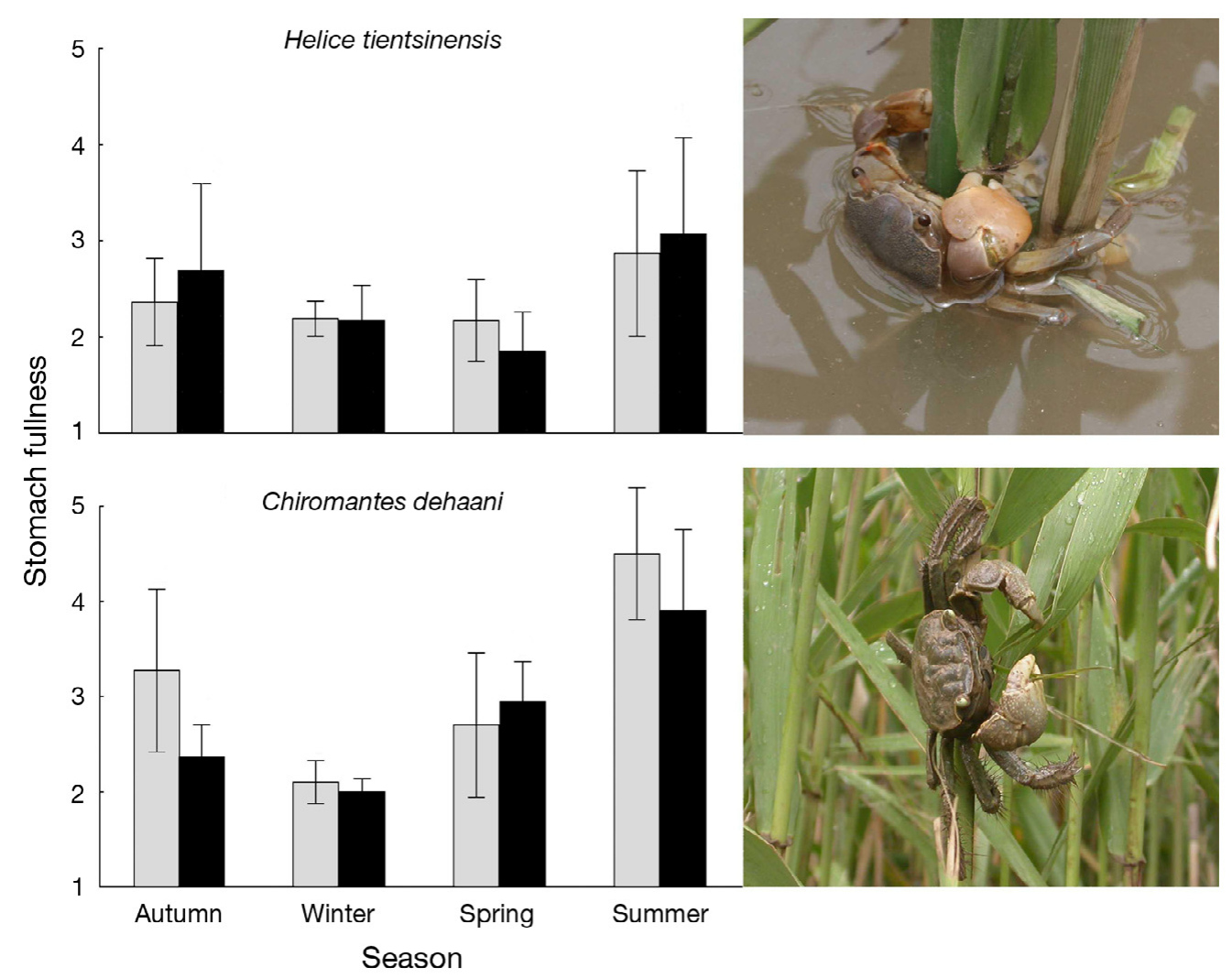

Fig. 2. Helice tientsinensis and Chiromantes dehaani. Stomach fullness analyses of 2 dominant crab species and photos showing their feeding behavior. (ロ) Crabs from Phragmites australis patches; ( $\square$ ) crabs from Spartina alterniflora patches. Error bars indicate $\mathrm{SE}$ ( $\mathrm{n}=10$ to $\sim 22$, depending on specimens available)

Table 4. Helice tientsinensis and Chiromantes dehaani. Stomach contents of the 2 most numerically abundant crab species from Spartina alterniflora (SA) and Phragmites australis (PA) monocultures. Relative abundance (mean \pm SE) of each food item are expressed as the proportional area of the food item in stomach contents mounted on microscope slides. Different superscript letters $(a, b)$ indicate significant differences between SA and PA in each season determined from $t$-tests $(p<0.05)$

\begin{tabular}{|c|c|c|c|c|c|c|}
\hline \multirow[t]{2}{*}{ Season } & \multirow[t]{2}{*}{ Vegetation } & \multirow[t]{2}{*}{$\mathrm{n}$} & \multicolumn{4}{|c|}{- Relative abundance of each food category $(\%)$} \\
\hline & & & Animal material & Plant material & Organic debris & Inorganic debris \\
\hline \multicolumn{7}{|c|}{ Helice tientsinensis } \\
\hline \multirow[t]{2}{*}{ Autumn } & SA & 10 & $6.59 \pm 6.59$ & $73.47 \pm 9.15$ & $8.00 \pm 3.92$ & $11.94 \pm 3.39^{\mathrm{a}}$ \\
\hline & $\mathrm{PA}$ & 10 & $8.08 \pm 6.49$ & $55.66 \pm 9.64$ & $3.61 \pm 1.37$ & $32.65 \pm 8.11^{\mathrm{b}}$ \\
\hline \multirow[t]{2}{*}{ Winter } & SA & 10 & $2.46 \pm 2.46$ & $34.81 \pm 6.58$ & $3.85 \pm 1.55$ & $58.88 \pm 6.67^{\mathrm{a}}$ \\
\hline & PA & 10 & $10.59 \pm 6.53$ & $50.88 \pm 9.34$ & $2.81 \pm 1.02$ & $35.72 \pm 7.32^{\mathrm{b}}$ \\
\hline \multirow[t]{2}{*}{ Spring } & SA & 10 & $6.24 \pm 6.24$ & $64.09 \pm 7.30^{\mathrm{a}}$ & $6.89 \pm 2.82$ & $22.78 \pm 4.68^{\mathrm{a}}$ \\
\hline & PA & 10 & $3.59 \pm 3.08$ & $37.64 \pm 8.23^{b}$ & $16.76 \pm 6.30$ & $42.01 \pm 7.56^{b}$ \\
\hline \multirow[t]{2}{*}{ Summer } & SA & 10 & $0.55 \pm 0.41$ & $75.85 \pm 4.26$ & $7.36 \pm 3.84$ & $16.23 \pm 4.23$ \\
\hline & PA & 10 & $4.60 \pm 2.88$ & $83.99 \pm 3.86$ & $2.72 \pm 0.89$ & $8.69 \pm 2.19$ \\
\hline \multicolumn{7}{|c|}{ Chiromantes dehaani } \\
\hline \multirow[t]{2}{*}{ Autumn } & SA & 10 & $0.18 \pm 0.18$ & $84.16 \pm 2.96^{\mathrm{a}}$ & $1.46 \pm 0.57$ & $14.20 \pm 2.64^{\mathrm{a}}$ \\
\hline & PA & 10 & $0.32 \pm 0.31$ & $61.51 \pm 8.21^{\mathrm{b}}$ & $2.86 \pm 0.84$ & $35.31 \pm 7.81^{\mathrm{b}}$ \\
\hline \multirow[t]{2}{*}{ Winter } & SA & 10 & $9.19 \pm 6.28$ & $59.05 \pm 7.31$ & $2.00 \pm 0.89$ & $29.84 \pm 3.67$ \\
\hline & PA & 10 & $10.11 \pm 9.70$ & $55.60 \pm 7.87$ & $1.91 \pm 0.56$ & $32.33 \pm 5.54$ \\
\hline \multirow[t]{2}{*}{ Spring } & SA & 10 & $0.71 \pm 0.29$ & $61.39 \pm 6.74$ & $3.03 \pm 0.99$ & $34.87 \pm 6.92$ \\
\hline & PA & 10 & $5.15 \pm 2.66$ & $52.77 \pm 8.22$ & $4.16 \pm 1.21$ & $37.92 \pm 8.03$ \\
\hline \multirow[t]{2}{*}{ Summer } & SA & 10 & $1.17 \pm 0.41$ & $83.67 \pm 3.25$ & $3.43 \pm 0.96$ & $11.74 \pm 2.78$ \\
\hline & PA & 10 & $1.02 \pm 0.47$ & $70.15 \pm 6.31$ & $2.67 \pm 0.91$ & $26.16 \pm 6.73$ \\
\hline
\end{tabular}


Table 5. Helice tientsinensis and Chiromantes dehaani. Composition of plant materials in stomach contents of the 2 most numerically abundant crab species from Spartina alterniflora (SA) and Phragmites australis (PA) monocultures. Relative abundance (mean $\pm \mathrm{SE}$ ) of each plant part is expressed as the proportional area within plant materials detected in stomach contents mounted on microscope slides. Different upper case letters $(\mathrm{a}, \mathrm{b})$ indicate significant differences between SA and PA in each season determined from $t$-tests $(\mathrm{p}<0.05)$.

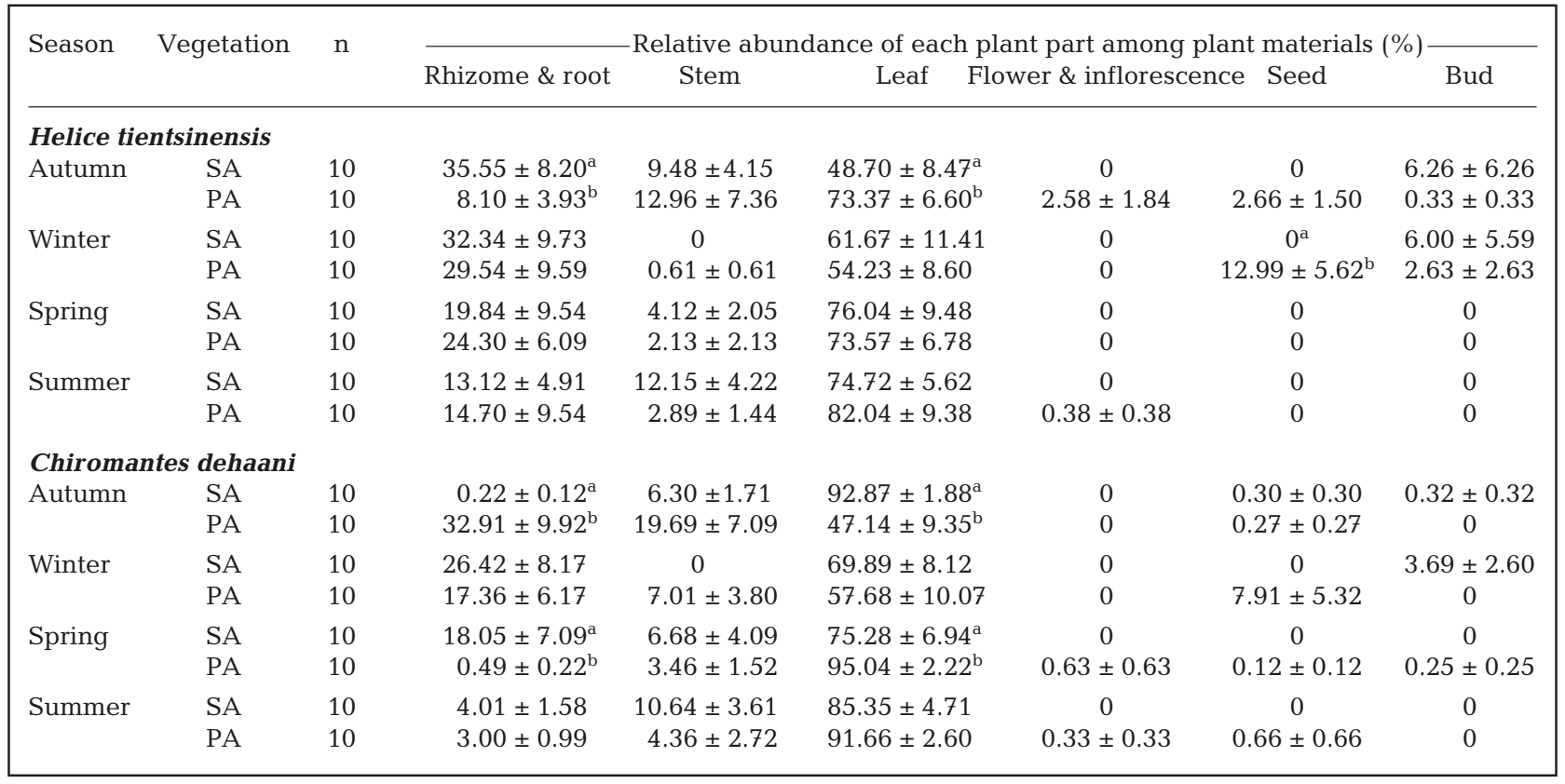

autumn, Helice tientsinensis ate more roots in Spartina alterniflora stands and more leaves in Phragmites australis stands. In spring, Chiromantes dehaani ate more roots and fewer leaves in $S$. alterniflora areas than in $P$. australis areas, whereas the opposite occurred in autumn (Table 5). In winter, the crabs ate seeds of $P$. australis but not of $S$. alterniflora.

Of the producers, the exotic Spartina alterniflora had a significantly higher $\delta^{13} \mathrm{C}$ value than the other primary producers, whereas Phragmites australis had the lowest $\delta^{13} \mathrm{C}$ value (Table 6). Benthic microalgae had significantly lower $\delta^{15} \mathrm{~N}$ values than did the vascular plants. Chiromantes dehaani and Helice tientsinensis from $P$. australis monocultures had similar $\delta^{13} \mathrm{C}$ values, and were significantly depleted compared with those from $S$. alterniflora patches (Fig. 3, Table 6). The $\delta^{15} \mathrm{~N}$ values of $H$. tientsinensis were generally higher than those of C. dehaani.
Table 6. Stable isotope $\delta^{13} \mathrm{C}$ and $\delta^{15} \mathrm{~N}$ values of main primary producers and crabs as consumers. Data are expressed as mean \pm SE. Different superscript lower case letters $(\mathrm{a}, \mathrm{b}, \mathrm{c})$ denote significant differences between plant autotrophs; different superscript upper case letters (A, B) indicate significant differences between crab species. PA: Phragmites australis; SA: Spartina alterniflora

\begin{tabular}{|lccc|}
\hline Sample & $\begin{array}{c}\text { Sample size } \\
(\mathrm{n})\end{array}$ & $\delta^{13} \mathrm{C}(\%)$ & $\delta^{15} \mathrm{~N}(\%)$ \\
\hline Producers & & & \\
$\begin{array}{l}\text { Phragmites australis (PA) } \\
\text { Spartina alterniflora (SA) }\end{array}$ & 4 & $-26.92 \pm 0.23^{\mathrm{a}}$ & $6.09 \pm 0.37^{\mathrm{a}}$ \\
$\begin{array}{l}\text { Benthic microalgae (BMI) } \\
\text { Consumers (crabs) }\end{array}$ & 6 & $-12.65 \pm 0.03^{\mathrm{b}}$ & $6.02 \pm 0.29^{\mathrm{a}}$ \\
Helice tientsinensis from PA & 6 & $-21.63 \pm 0.31^{\mathrm{A}}$ & $8.25 \pm 0.39^{\mathrm{A}}$ \\
Helice tientsinensis from SA & 6 & $-17.52 \pm 0.68^{\mathrm{B}}$ & $8.04 \pm 0.38^{\mathrm{A}}$ \\
Chiromantes dehaani from PA & 6 & $-22.67 \pm 0.58^{\mathrm{A}}$ & $7.54 \pm 0.21^{\mathrm{A}, \mathrm{B}}$ \\
Chiromantes dehaani from SA & 6 & $-16.07 \pm 0.63^{\mathrm{B}}$ & $6.96 \pm 0.38^{\mathrm{B}}$ \\
\hline
\end{tabular}

\section{DISCUSSION}

\section{Effects of plant type on crab communities}

This is the first study to reveal the effects of an invasive saltmarsh plant on crab communities and relate the changes of crab distributions to their feeding habits by means of gut contents and stable isotope analyses. Our study showed that the Spartina alterniflora invasion has had a positive effect on borrowing crab populations in the salt marshes of the Yangtze River estuary, mainly because the 2 dominate grapsoid crabs, Chiromantes dehaani and Helice tientsinensis, preferred S. alterniflora over the native Phragmites australis communities as habitats. Other in- 

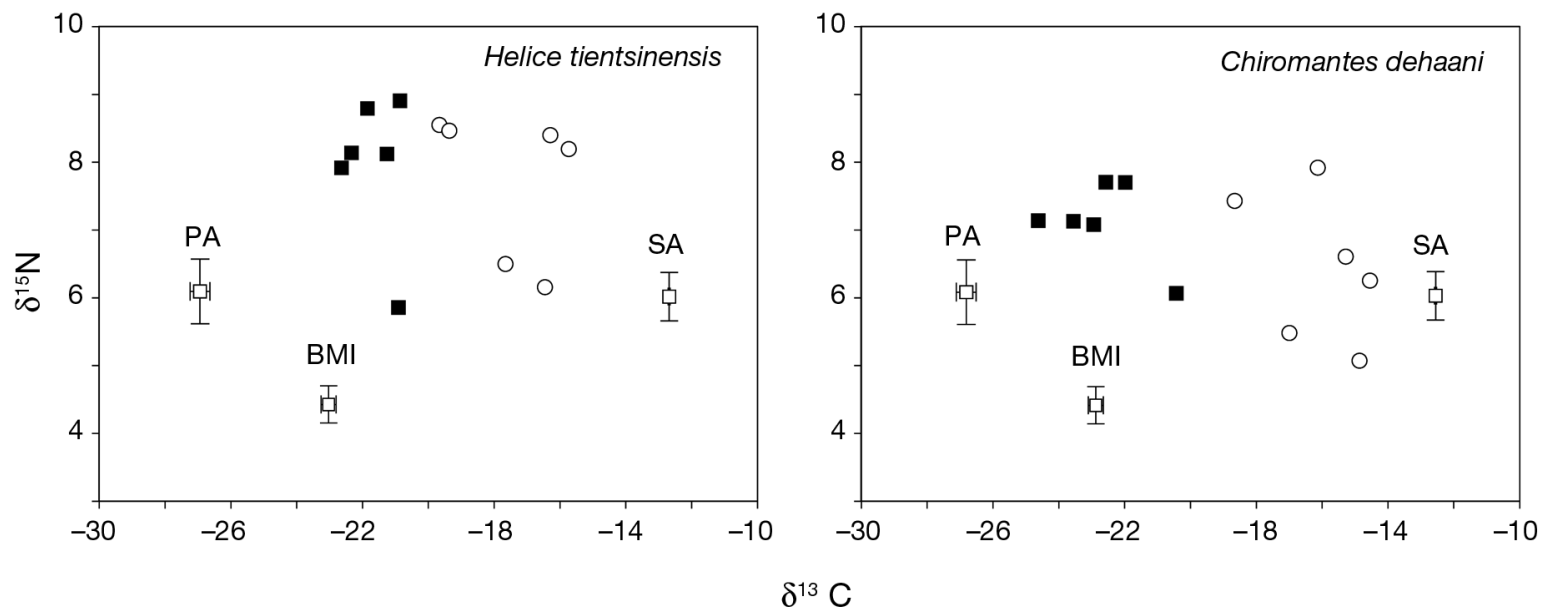

Fig. 3. Helice tientsinensis and Chiromantes dehaani. Dual isotope $\left(\delta^{13} \mathrm{C}\right.$ and $\left.\delta^{15} \mathrm{~N}\right)$ plots of primary producers and crab consumers. Primary producer $(\square)$ data are shown as means \pm SE, whereas crab data are shown as individual plots. (ם) Crabs from

Phragmites australis (PA) monocultures; (O) crabs from Spartina alterniflora (SA) monocultures. BMI: benthic microalgae

vestigations also indicated that the $S$. alterniflora communities are more favorable for crabs than are $P$. australis communities. In Delaware Bay, USA, where $P$. australis has invaded $S$. alterniflora communities, the blue crab Callinectes sapidus prefers $S$. alterniflora over P. australis habitats (Jivoff \& Able 2003). Wang et al. (2008) reported that the invasive $S$. alterniflora enhanced densities of $C$. dehaani compared with the native $P$. australis, which was confirmed in this study.

\section{Environmental factors influencing the crab distribution}

Vegetation might affect crab communities through a series of physical, chemical and biological changes in the benthic systems (Nomann \& Pennings 1998, Peterson et al. 2001). Our study identified sediment grain size, water content and vegetation canopy structure (e.g. stem height) as the main factors influencing the crab distributions.

Density variations in intertidal crabs were shown to be related to sediment grain size (Katrak et al. 2008, Wang et al. 2009). Seiple (1979) found that Sesarma cinereum habitats were characterized by sandy substrates, whereas $S$. reticulatum inhabited substrates with high silt content. Bertness et al. (2009) found that the burrow density, depth, and complexity of $S$. reticulatum were higher on peat substrate than on sand or mud substrate. The highest Helice crassa densities corresponded to soft and muddy substrata in New Zealand estuaries (Jones \& Simons 1983). In our study area, Chiromantes dehaani and $H$. tientsinensis densities were higher in Spartina alterniflora communities, which tended to accumulate more fine-grained parti- cles than did the adjacent Phragmites australis marshes.

Plant canopy characteristics such as stem height and density are important determinants of macrofauna community structures (Netto \& Lana 1999). The distribution and abundance of fiddler crab Uca pugnax were found to be related to the density of Spartina root mats (Ringold 1979, Bertness \& Miller 1984). In our study, Spartina alterniflora had higher stem density and lower height than did the native Phragmites australis. This implied that $S$. alterniflora may provide a more benign habitat for crabs than $P$. australis. $S$. alterniflora has $70 \%$ greater root biomass than $P$. australis (Liao et al. 2007); therefore, the belowground structure of $S$. alterniflora would also have effects on the distribution of crabs. Wu (1959) reported that Chiromantes dehaani prefers moist environments. The moister environment provided by $S$. alterniflora may be one of the reasons why more crabs were found in patches of this plant.

\section{Feeding activities of the 2 dominant grapsoid crabs}

The stomach fullness of Chiromantes dehaani and Helice tientsinensis from the invasive Spartina alterniflora and the native Phragmites australis communities were similar. This suggests that the crabs found similar amounts of food in communities composed of different plant species.

Plant materials were the major component in the diet of both Chiromantes dehaani and Helice tientsinensis from both Spartina alterniflora and Phragmites australis marshes. Therefore, both crabs were primarily herbivores based on their natural diets. C. dehaani is 
generally reported to be an herbivore (Feng \& Guan 1964), but it also eats juvenile crabs and can consume 80 to $85 \%$ in animal foods in laboratory feeding experiments (Feng \& Guan 1964, Kneib et al. 1999). The feeding habits of $H$. tientsinensis are unknown to date. However, the congener $H$. tridens has been reported to rely mostly on plant matter (Kuroda et al. 2005); and $H$. formosensis is primarily regarded as a carnivore, consuming 75.1 to $82.5 \%$ in animal materials (Mia et al. 2001). Our field observations found that both $H$. tientsinensis and $C$. dehaani attacked other crabs, fish and crustaceans. Animal materials, including gastropods, isopods and crustaceans, were also detected in their stomachs. Therefore, these helicid and sesarmid crabs are probably omnivores, but have flexible diets depending on food availability. The present study revealed that $H$. tientsinensis and $C$. dehaani did not shift their feeding habits in marshes of different plant species, and both ingested plants as a major food category. This was confirmed by similar $\delta^{15} \mathrm{~N}$ values for $H$. tientsinensis and $C$. dehaani from different stands of plants.

Among the vascular plant materials consumed by the crabs, leaves were the major items and rhizomes/ roots were next in importance in both Spartina alterniflora and Phragmites australis stands. Plant rhizomes/ roots were probably a substitute for leaves. In autumn, for example, Helice tientsinensis consumed more leaves and fewer rhizomes/roots in P. australis communities than in $S$. alterniflora communities, but they consumed more rhizomes/roots and fewer leaves in $S$. alterniflora communities. In contrast, Chiromantes dehaani ate more rhizomes/roots and fewer leaves in $P$. australis communities in autumn, but ingested more leaves and fewer rhizomes/roots in S. alterniflora communities in this season. The sympatric occurrence of crabs at high densities is common in estuaries and salt marshes. The coexistence of different crab species may be achieved by intraguild predation or niche partitioning (Kuroda et al. 2005). Our study may reflect the feeding strategies of 2 grapsoid crabs, $H$. tientsinensis and C. dehaani, that are able to coexist by alternatively feeding on leaves and rhizomes/roots. These 2 species probably exerted different top-down effects on the plant productivity.

A number of studies have reported that animals exhibit dietary shifts between native and invaded coastal habitats. Some of these studies have shown that benthic infaunal animals do not use invasive plants as a major carbon source (Brusati \& Grosholz 2007, Demopoulos et al. 2007). However, Wainright et al. (2000) reported that the mummichog Fundulus heteroclitus largely (73\%) relied on Phragmites australis in exotic $P$. australis-dominated marshes. In our study, as reported previously (e.g. Quan et al. 2007), Spartina alterniflora had significantly more enriched $\delta^{13} \mathrm{C}$ values than $\operatorname{did} P$. australis. For both Chiromantes dehaani and Helice tientsinensis, crabs from $S$. alterniflora patches were significantly more enriched in $\delta^{13} \mathrm{C}$ values than those from $P$. australis patches. This finding suggested that the crab consumers were likely to eat vegetation materials of different plant species. Through a feeding preference experiment, C. dehaani was found to prefer $S$. alterniflora to $P$. australis (Wang et al. 2008). Together these results suggest that the invasive $S$. alterniflora can provide as significant a carbon source for herbivorous crabs as that provided by the native plant species.

\section{CONCLUSION AND IMPLICATIONS}

In conclusion, stands of invasive Spartina alterniflora supported about $42 \%$ higher crab densities than was supported in adjacent native Phragmites australis stands, mainly because 2 dominant grapsoid crabs, Chiromantes dehaani and Helice tientsinensis, preferred $S$. alterniflora communities. Because the plant stems of $S$. alterniflora were generally denser and lower than those of $P$. australis, $S$. alterniflora may provide more benign environmental conditions than does $P$. australis. Dietary analyses revealed that the crabs did not change their feeding habits and continued to act as herbivores in invasive vegetation, and stable isotope analyses revealed that crabs use $S$. alterniflora as an important carbon source. Levin et al. (2006) reported a relationship between diet and tolerance to invasion and hypothesized that species that can consume invasive plants are more likely to inhabit invaded sediments than those that do not shift their diet. Our study supports this hypothesis and indicates that the non-selective feeding activities of $H$. tientsinensis and $C$. dehaani might be an important explanation for why they inhabit the invasive $S$. alterniflora stands.

The presence of crab burrows affects soil aeration, soil organic matter decomposition rates and material exchange between marshes and coastal waters (Minkoff et al. 2006, Daleo et al. 2007, Xin et al. 2009). With the invasion of Spartina alterniflora more crabs and more burrows will possibly lead to changes in sediment dynamics of the Yangtze River estuarine marshes. Our previous studies at Chongming Dongtan indicated that the macroinfauna density tended to decrease in the invasive $S$. alterniflora communities (Chen et al. 2009). Because the presence of intertidal crabs is known to depress macrofaunal activities (Neira et al. 2006), the decreased infaunal densities in $S$. alterniflora patches may partly be related to the increased crab abundance. The marsh crab larvae are one of the important food sources for estuarine fish and 
are regarded to be an essential biological export of marsh elements when released (Wooldridge \& Loubser 1996, Costa et al. 2009). The enhanced crab densities at the Yangtze River estuarine salt marshes and the shifted carbon sources in their diets would possibly affect the carbon export from the marshes to the open water through the crab larvae.

Acknowledgements. We thank Binsong Jin and Li Guo for their help in field sampling, M. D. Bertness, J. P. Montoya and Jun Li for their constructive comments. This research was supported by the National Basic Research Program of China (2006CB403305), NSFC fund (30930019, 40876044), and Science and Technology Department of Shanghai (08231200705, 10dz1200700).

\section{LITERATURE CITED}

Bas C, Luppi T, Spivak E (2005) Population structure of the South American estuarine crab, Chasmagnathus granulatus (Brachyura, Varunidae) near the southern limit of its geographical distribution: comparison with northern populations. Hydrobiologia 537:217-228

Bertness MD (1985) Fiddler crab regulation of Spartina alterniflora production on a New England saltmarsh. Ecology 66:1042-1055

Bertness MD (1999) The ecology of Atlantic shorelines. Sinauer Associates, Sunderland, MA

Bertness MD, Miller T (1984) The distribution and dynamics of Uca pugnax (Smith) burrows in a New England saltmarsh. J Exp Mar Biol Ecol 83:211-237

Bertness MD, Holdredge C, Altieri AH (2009) Substrate mediates consumer control of salt marsh cordgrass on Cape Cod, New England. Ecology 90:2108-2117

Bortolus A, Schwindt E, Iribarne O (2002) Positive plant-animal interactions in the high marsh of an Argentinean coastal lagoon. Ecology 83:733-742

Brusati ED, Grosholz ED (2007) Effect of native and invasive cordgrass on Macoma petalum density, growth, and isotopic signatures. Estuar Coast Shelf Sci 71:517-522

Chen HL, Li B, Hu JB, Chen JK, Wu JH (2007) Effects of Spartina alterniflora invasion on benthic nematode communities in the Yangtze Estuary. Mar Ecol Prog Ser 336: 99-110

Chen ZB, Guo L, Jin BS, Wu JH, Zheng GH (2009) Effect of the exotic plant Spartina alterniflora on macrobenthos communities in salt marshes of the Yangtze River Estuary, China. Estuar Coast Shelf Sci 82:265-272

Clarke KR, Ainsworth M (1993) A method for linking multivariate community structure to environmental variables. Mar Ecol Prog Ser 92:205-209

Costa PV, da Silva UAT, Ventura R, Ostrensky A, Angelo L (2009) Fish predation on brachyuran larvae and juveniles in the Pinheiros River, Guaratuba Bay, Parana, Brazil. Zoologia 26:231-240

> Daleo P, Fanjul E, Casariego AM, Silliman BR, Bertness MD, Iribarne O (2007) Ecosystem engineers activate mycorrhizal mutualism in salt marshes. Ecol Lett 10:902-908

> Demopoulos AWJ, Fry B, Smith CR (2007) Food web structure in exotic and native mangroves: a Hawaii-Puerto Rico comparison. Oecologia 153:675-686

> Escapa M, Perillo GME, Iribarne O (2008) Sediment dynamics modulated by burrowing crab activities in contrasting SW
Atlantic intertidal habitats. Estuar Coast Shelf Sci 80: 365-373

Fanjul E, Grela MA, Canepuccia A, Iribarne O (2008) The Southwest Atlantic intertidal burrowing crab Neohelice granulata modifies nutrient loads of phreatic waters entering coastal area. Estuar Coast Shelf Sci 79:300-306

Feng ZX, Guan RY (1964) Feeding habit of Sesarma dehaani and its relationship with agriculture. Chin J Zool 2:81-82

Grosholz E (2002) Ecological and evolutionary consequences of coastal invasions. Trends Ecol Evol 17:22-27

> Hoffman JA, Katz J, Bertness MD (1984) Fiddler crab deposition-feeding and meiofaunal abundance in saltmarsh habitats. J Exp Mar Biol Ecol 82:161-174

Huang H, Zhang L, Gao Z (2005) The vegetation resource at the intertidal zone in Shanghai using remote sensing. Acta Ecol Sin 25:2686-2693

Jivoff PR, Able KW (2003) Blue crab, Callinectes sapidus, responses to the invasive common reed, Phragmites australis: abundance, size, sex ratio and molting frequency. Estuaries 26:587-595

> Johnston D, Freeman J (2005) Dietary preference and digestive enzyme activities as indicators of trophic resource utilization by six species of crab. Biol Bull (Woods Hole) 208: $36-46$

Jones MB, Simons MJ (1983) Latitudinal variation in reproductive characteristics of a mud crab, Helice crassa (Grapsidae). Bull Mar Sci 33:656-670

Katrak G, Dittmann S, Seuront L (2008) Spatial variation in burrow morphology of the mud shore crab Helograpsus haswellianus (Brachyura, Grapsidae) in South Australian saltmarshes. Mar Freshw Res 59:902-911

> Kneib RT, Lee SY, Kneib JP (1999) Adult-juvenile interactions in the crabs Sesarma (Perisesarma) bidens and $S$. (Holometopus) dehaani (Decapoda: Grapsidae) from intertidal mangrove habitats in Hong Kong. J Exp Mar Biol Ecol 234: 255-273

Kuroda M, Wada K, Kamada M (2005) Factors influencing coexistence of two brachyuran crabs, Helice tridens and Parasesarma plicatum, in an estuarine salt marsh, Japan. J Crustac Biol 25:146-153

> Levin LA, Neira C, Grosholz ED (2006) Invasive cordgrass modifies wetland trophic function. Ecology 87:419-432

> Li B, Liao CZ, Zhang XD, Chen HL and others (2009) Spartina alterniflora invasions in the Yangtze River estuary, China: an overview of current status and ecosystem effects. Ecol Eng 35:511-520

> Liao CZ, Luo YQ, Jiang LF, Zhou XH and others (2007) Invasion of Spartina alterniflora enhanced ecosystem carbon and nitrogen stocks in the Yangtze Estuary, China. Ecosystems 10:1351-1361

McCraith BJ, Gardner LR, Wethey DS, Moore WS (2003) The effect of fiddler crab burrowing on sediment mixing and radionuclide profiles along a topographic gradient in a southeastern salt marsh. J Mar Res 61:359-390

> Mia Y, Shokita S, Watanabe S (2001) Stomach contents of two grapsid crabs, Helice formosensis and Helice leachi. Fish Sci 67:173-175

Minkoff DR, Escapa M, Ferramola FE, Maraschin SD, Pierini JO, Perillo GME, Delrieux C (2006) Effects of crab-halophytic plant interactions on creek growth in a S.W. Atlantic salt marsh: a cellular automata model. Estuar Coast Shelf Sci 69:403-413

> Neira C, Grosholz ED, Levin LA, Blake R (2006) Mechanisms generating modification of benthos following tidal flat invasion by a Spartina hybrid. Ecol Appl 16:1391-1404

> Netto SA, Lana PC (1999) The role of above- and belowground components of Spartina alterniflora (Loisel) and 
detritus biomass in structuring macrobenthic associations of Paranagua Bay (SE, Brazil). Hydrobiologia 400:167-177

Ng PK, Guinot D, Davie PJF (2008) Systema Brachyurorum: part I. an annotated checklist of extant brachyuran crabs of the world. Raffles Bull Zool (Suppl) 17:1-286

Nomann BE, Pennings SC (1998) Fiddler crab-vegetation interactions in hypersaline habitats. J Exp Mar Biol Ecol 225:53-68

Peterson BJ, Thompson KR, Cowan JH, Heck KL (2001) Comparison of predation pressure in temperate and subtropical regions based on chronographic tethering. Mar Ecol Prog Ser 224:77-85

Posey MH, Alphin TD, Meyer DL, Johnson JM (2003) Benthic communities of common reed Phragmites australis and marsh cordgrass Spartina alterniflora marshes in Chesapeake Bay. Mar Ecol Prog Ser 261:51-61

Quan WM, Fu CZ, Jin BS, Luo YQ, Li B, Chen JK, Wu JH (2007) Tidal marshes as energy sources for commercially important nektonic organisms: stable isotope analysis. Mar Ecol Prog Ser 352:89-99

Riera P, Stal LJ, Nieuwenhuize J, Richard P, Blanchard G, Gentil F (1999) Determination of food sources for benthic invertebrates in a salt marsh (Aiguillon Bay, France) by carbon and nitrogen stable isotopes: importance of locally produced sources. Mar Ecol Prog Ser 187:301-307

Ringold P (1979) Burrowing, root mat density, and the distribution of fiddler crabs in the eastern United States. J Exp Mar Biol Ecol 36:11-21

Seiple W (1979) Distribution, habitat preferences and breeding periods in the crustaceans Sesarma cinereum and Sesarma reticulatum (Brachyura, Decapoda, Grapsidae). Mar Biol 52:77-86

Spivak ED, Anger K, Bas CC, Luppi TA, Ismael D (1996) Size structure, sex ratio, and breeding season in two intertidal grapsid crab species from Mar Chiquita Lagoon, Argentina. Neritica 10:7-26

Editorial responsibility: Hans Heinrich Janssen Oldendorf/Luhe, Germany
Takeda S, Kurihara Y (1987) The distribution and abundance of Helice tridens (De Haan) burrows and substratum conditions in a northeastern Japan saltmarsh (Crustacea, Brachyura). J Exp Mar Biol Ecol 107:9-19

Talley TS, Levin LA (2001) Modification of sediments and macrofauna by an invasive marsh plant. Biol Invasions 3: 51-68

Wainright SC, Weinstein MP, Able KW, Currin CA (2000) Relative importance of benthic microalgae, phytoplankton and the detritus of smooth cordgrass Spartina alterniflora and the common reed Phragmites australis to brackishmarsh food webs. Mar Ecol Prog Ser 200:77-91

Wang Q, Wang CH, Zhao B, Ma ZJ, Luo YQ, Chen JK, Li B (2006) Effects of growing conditions on the growth of and interactions between salt marsh plants: implications for invasibility of habitats. Biol Invasions 8:1547-1560

Wang JQ, Zhang XD, Nie M, Fu CZ, Chen JK, Li B (2008) Exotic Spartina alterniflora provides compatible habitats for native estuarine crab Sesarma dehaani in the Yangtze River estuary. Ecol Eng 34:57-64

Wang JQ, Tang L, Zhang XD, Wang CH and others (2009) Fine-scale environmental heterogeneities of tidal creeks affect distribution of crab burrows in a Chinese salt marsh. Ecol Eng 35:1685-1692

> Wooldridge TH, Loubser H (1996) Larval release rhythms and tidal exchange in the estuarine mudprawn, Upogebia africana. Hydrobiologia 337:113-121

Wu XG (1959) A preliminary observation of several amphibious crabs in Guangdong province. Biol Bull (Woods Hole) 4:154-157

Xin P, Jin GQ, Li L, Barry DA (2009) Effects of crab burrows on pore water flows in salt marshes. Adv Water Resour 32: 439-449

Xu HF, Zhao YL (2005) Scientific Survey on Chongming Dongtan Migratory Birds Nature Reserve of Shanghai. Chinese Forestry Press, Beijing

Submitted: February 20, 2010; Accepted: August 13, 2010 Proofs received from author(s): September 20, 2010 